\title{
Demographics of the Open-Globe Injuries in Pediatric Age Group in Northwest Turkey
}

\section{Türkiye'nin Kuzeybatısındaki Pediatrik Yaş Grubunda Delici Göz Yaralanmaları Demografisi}

\author{
Sertaç Argun Kıvanç, Berna Akova Budak, Ahmet Tuncer Özmen, Meral Yıldız, Mediha Tok Çevik, Nagihan Amuk Hamidi
}

Uludağ University Faculty of Medicine, Department of Ophthalmology, Bursa, Turkey

Keywords

Open globe injury, pediatric, trauma, eye injuries, eye trauma, intraocular foreign body

\section{Anahtar kelimeler \\ Delici göz yaralanması, pediatrik, travma, göz yaralanması, göz travması, göz içi yabancı cisim}

Received/Geliş Tarihi : 07.03.2016

Accepted/Kabul Tarihi : 21.04 .2016

DOI:10.4274/jcp.63935

Address for Correspondence/Yazışma Adresi: Berna Akova Budak, MD, Uludağ University Faculty of Medicine, Department of Ophthalmology, Bursa, Turkey

Phone: +90 5324923134

E-mail: bernaakova@hotmail.com

\footnotetext{
$\left.{ }^{(}\right)$The Journal of Current Pediatrics, Published by Galenos Publishing House.

This article is distributed under the terms of the "Creative Commons Attribution NonCommercial 4.0 International Licence (CC BY-NC 4.0)".
}

\begin{abstract}
Introduction: Our aim was to investigate the pattern of open globe injury and assess the effect of age on different parameters of open globe injury in pediatric patients.

Materials and Methods: The medical records of the patients under 18 years old who had open-globe injury were retrospectively reviewed. Age, gender, the cause of the trauma, presence of intraocular foreign body and the extent of the ocular damage were recorded.

Results: The study was comprised of 79 patients ( 23 female, 56 male) with a mean age of 7.7 \pm 4.4 (range: $2-18$ years). Thirty-nine patients were injured with a blunt tip object, 27 with a sharp object and one has rupture with trauma. Thirty-five injuries occurred outside and 45 at home. The season in which most of the injuries took place was summer (32\%). Seventy-five percent of the injuries were noted in 11 years and under. The mean age subject to blunt tip object injury, organic body injury and outdoor injury was significantly higher compared to that of with sharp object, inorganic body injury and indoor injury.

Conclusions: The open globe-injury rates in Northwest Turkey is found to be higher in smaller age groups. Making the parents aware of the danger and consequences of the trauma and avoiding the easily accessible sharp objects may decrease the trauma rates.
\end{abstract}

$\ddot{\mathbf{O} z}$

Giriş: Amacımız, pediatrik yaş grubunda meydana gelen delici göz yaralanmalarını araştırmak ve çocukların yaşının delici göz yaralanmalarında değişik parametreler üzerine etkisini incelemekti.

Gereç ve Yöntem: Delici göz yaralanması geçirmiş 18 yaş altındaki hastaların medikal kayıtları geriye dönük olarak incelendi. Yaş, cinsiyet, travma sebebi, göz içinde yabancı cisim bulunma durumu ve göz yaralanmasının kapsamı not edildi. Bulgular: Çalışmaya 79 hasta ( $23 \mathrm{kız}, 56$ erkek) dahil edildi. Ortalama yaşları

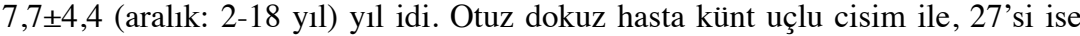
keskin uçlu cisim ile yaralanmıştı. Bir hastanın da travma sonucu glob rüptürü mevcuttu. Otuz beş yaralanma dış mekanlarda gerçekleşmiş iken 45'i evde gerçekleşmişti. En çok yaralanma yaz aylarında olmuştu (\%32). Yaralanmaların \% 75'i 11 yaş ve altında gerçekleşmişti. Ortalama yaralanma yaşı künt obje, organik cisim ve dış mekanda olanlarda; keskin cisimle, inorganik cisimlerle ve iç mekanda olanlardan anlamlı derecede yüksek idi.

Sonuç: Türkiye'nin Kuzeybatısında delici göz yaralanma oranları daha düşük yaşlarda daha yüksek bulundu. Aileleri tehlikeler ve travmanın sonuçları konusunda haberdar etmek ve kolaylık ile ulaşılabilecek keskin cisimlerin önlemini almak travma oranlarını azaltabilir. 


\section{Introduction}

Ocular traumas, especially open globe injuries, have always been one of the most frequent causes of blindness at childhood (1). Age is one of the most important risk factors for pediatric ocular traumas $(2,3)$. Causes of open globe injuries are variable in different age groups (4). In different studies, different age groups have been defined and different results have been reported for age groups. While some studies showed younger age groups are affected most, the others showed opposite results (5-7). Twenty-one percent of hospitalizations of ophthalmology department are open globe injuries. Young adults (18-20 year-old) are the most hospitalized group for eye injury in United States (8). Injuries from desk supplies peaked in the 5-8 years age groups and toy injuries were most common in 2 to 4-year-olds (4). Though the impact of pediatric age groups on ocular trauma has been revealed, the effect of age on various parameters has not been studied in detail. In this retrospective study we investigated the pattern of open globe injury and we tried to define age, as a parameter for open globe injuries; and we defined three pediatric age groups and compared them in terms of trauma sources and its effects.

\section{Materials and Methods}

The medical records of patients under 18-year-old presenting between January 2010 and December 2013 with open-globe injury to the Uludağ University Faculty of Medicine, Department of Ophthalmology, which is the biggest tertiary centre in Northwest Turkey, were retrospectively reviewed. The study was approved by the institution and adheres to the tenets of the declaration of Helsinki. Informed consent was obtained from all individual participants' parents included in the study. All patients were initially evaluated at emergency and then hospitalized for primary repair. Age, gender, the cause of the trauma, presence of intraocular foreign body and the extent of the ocular damage were recorded. The primary repair of the patients who were enrolled in the study was performed by the same surgeon. The study included 79 patients aged between 2-17 years old. These children were grouped into 3 different age groups according to the neurological and biologic development defined by Williams et al. (9). The group 1 included early childhood (age range: 2-5), group 2 middle childhood (age range: 6-11), group 3 early adolescent period (age range: 12-17) respectively. These groups were compared in terms of the defined parameters.

\section{Statistical Analysis}

For statistical analysis SPSS 17 program was used. Descriptive statistical methods were used to assess the study data. Oneway ANOVA test was used for comparison of quantitative data. For comparison of qualitative data Pearson chi-square and Fisher's exact test were used. Statistical significance was set at $\mathrm{p}<0.05$.

\section{Results}

The study comprised 79 patients (23 females, 56 males) with a mean age of $7.7 \pm 4.4$ (range: $2-18$ ) years. Thirty-six right, 43 left eyes were involved in the injury. The known objects causing the trauma were divided into 2 groups as blunt tip and sharp. Thirty-nine patients were injured with a blunt tip, 27 with a sharp object and one has rupture with trauma. The cause of the trauma was undefined in 12 patients. Thirty-four injuries occurred outside and 45 at home. The season in which most of the injuries took place was summer (32\%), between May and September. The distribution of injuries according to months and the means of age according to months are shown in Figure 1.

Forty-eight patients had corneal, nine had scleral and 22 had corneoscleral injuries, respectively. Intraocular foreign body was identified in six patients

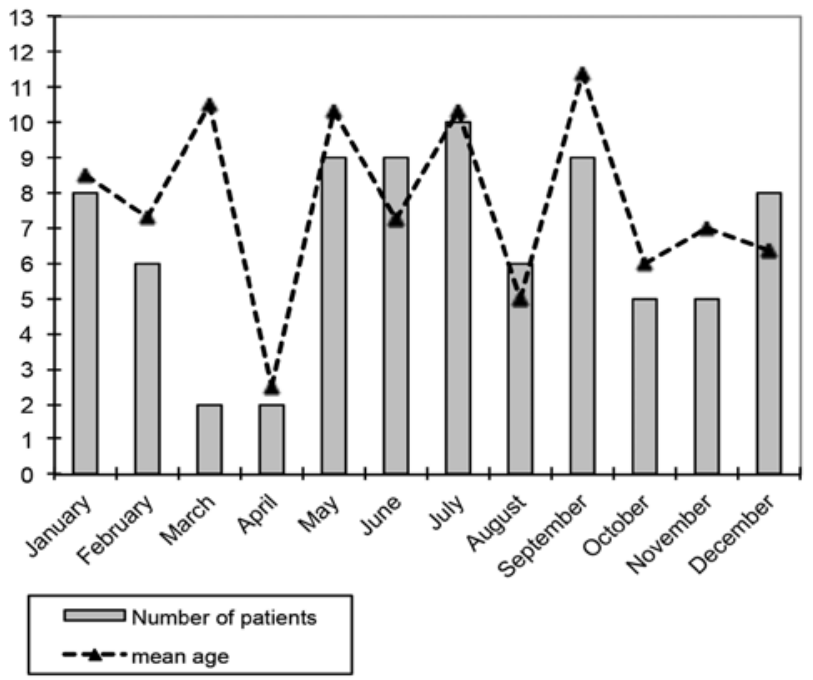

Figure 1. Distributions of number of the patients and means age of the open globe injuries 
(7.6\%) Sixty-seven percent of the patients had referred to our clinic in 24 hours following the injury, only 2 had referred after 48 hours. The injuries were caused by organic material in eight $(10 \%)$ patients. The gender, injured eye, the relation of age with the object causing the trauma, the relation of age with the seasons and the place where the injury had occurred is given in Table 1. The age subject to blunt tip object injury was significantly higher compared to that of with sharp object, as well as the age subject to organic body injury was significantly higher than the age subject to inorganic body injury. Again, the age subject to outdoor injury was found to be significantly higher than indoor injury $(\mathrm{p}<0.05)$.

The relation of intraocular and adnexial injury by the object causing the trauma, presence of intraocular foreign body and the need for 2 or more operations following the primary repair respectively with age is shown in Table 2. The comparison of three age groups is given in Tables 3, 4, 5. While most of the ocular injury occurred in fall in 2-5 age group, 6-11 and 12-18 groups had injury in summer at most. Most of the children with open globe injury were in group 1 . Seventy-five percent of the injuries were noted in 11 years and under. Iris injury was found in 53\% of 12-18 age group and was significantly higher compared to other groups $(\mathrm{p}<0.01)$. The outdoor injuries were also significantly higher than indoor injuries in that group $(p<0.05)$. The adnexial injuries were encountered only in five patients but it is remarkable that all the patients were in group $1(\mathrm{p}=0.024)$.

\section{Discussion}

The second most common cause of childhood monocular blindness is trauma. The open globe injuries have been the third cause of hospitalization for the pediatric ocular trauma in USA following the open wound injuries of ocular adnexa and orbital floor fractures (8). In one study conducted in Turkey, $43 \%$ of all ocular trauma occurred in age group younger than 18 years old (10).

In this retrospective study we defined 3 different age groups as 2-5, 6-11 and 12-17 years according to pediatric neurological and physical development. We could not find any significant statistical difference in terms of different parameters between groups except iris trauma and the place of the trauma. However when we assessed parameters regarding age, we found significant difference with iris trauma, place of the trauma, properties of the

Table 1. The gender, injured eye, the relation of age with the object causing the trauma, the relation of age with the seasons and the place where the injury had occurred

\begin{tabular}{|c|c|c|c|c|c|c|c|c|c|c|}
\hline & \multicolumn{4}{|c|}{ Gender } & $\mathrm{p}$ value & \multicolumn{4}{|c|}{ Injured eye } & \multirow[t]{2}{*}{$\mathrm{p}$ value } \\
\hline & Gir & & Bo & & & Right & & Left & & \\
\hline & $\mathrm{n}$ & Mean \pm SD & $\mathrm{n}$ & Mean \pm SD & & $\mathrm{n}$ & Mean \pm SD & $\mathrm{n}$ & Mean \pm SD & \\
\hline \multirow{13}{*}{$\underset{⿱ ㇒}{\mathbb{U}}$} & 23 & $7.7 \pm 4.0$ & 56 & $7.7 \pm 4.6$ & 0.969 & 30 & $7.0 \pm 4.1$ & 33 & $7.6 \pm 4.5$ & 0.620 \\
\hline & \multicolumn{4}{|c|}{ Cause of the injury } & $\mathrm{p}$ value & \multicolumn{4}{|c|}{ Known/unknown causes } & $\mathrm{p}$ value \\
\hline & Blu & ip objects & Sh & objects & & \multicolumn{2}{|l|}{ Known } & \multicolumn{2}{|c|}{ Unknown } & \\
\hline & $\mathrm{n}$ & Mean \pm SD & $\mathrm{n}$ & Mean \pm SD & & $\mathrm{n}$ & Mean $\pm \mathrm{SD}$ & $\mathrm{n}$ & Mean \pm SD & \\
\hline & 39 & $8.5 \pm 5.0$ & 27 & $6.2 \pm 3.2$ & 0.043 & 67 & $7.6 \pm 4.5$ & 12 & $8.4 \pm 4.4$ & 0.545 \\
\hline & \multicolumn{4}{|c|}{ Place of the injury } & $\mathrm{p}$ value & \multicolumn{4}{|c|}{ Injury with organic/inorganic objects } & $\mathrm{p}$ value \\
\hline & \multicolumn{2}{|c|}{ Home } & \multicolumn{2}{|c|}{ Outside } & & \multicolumn{2}{|l|}{ Organic } & \multicolumn{2}{|c|}{ Inorganic } & \\
\hline & $\mathrm{n}$ & Mean \pm SD & $\mathrm{n}$ & Mean \pm SD & & $\mathrm{n}$ & Mean \pm SD & $\mathrm{n}$ & Mean \pm SD & \\
\hline & 45 & $6.6 \pm 3.7$ & 34 & $9.1 \pm 4.9$ & 0.013 & 8 & $10.3 \pm 4.3$ & 57 & $7.0 \pm 4.2$ & 0.046 \\
\hline & \multicolumn{10}{|c|}{ Means of the age according to seasons } \\
\hline & \multicolumn{2}{|c|}{ Winter } & \multicolumn{2}{|c|}{ Spring } & & \multicolumn{2}{|l|}{ Summer } & \multicolumn{2}{|c|}{ Autumn } & $\mathrm{p}$ value \\
\hline & $\mathrm{n}$ & Mean \pm SD & $\mathrm{n}$ & Mean \pm SD & & $\mathrm{n}$ & Mean \pm SD & $\mathrm{n}$ & Mean \pm SD & \\
\hline & 22 & $7.4 \pm 4.4$ & 13 & $9.1 \pm 5.1$ & & 25 & $8.7 \pm 4.5$ & 19 & $5.8 \pm 3.4$ & 0.099 \\
\hline
\end{tabular}


object which caused the trauma, additional adnexial damage, need for a secondary operation.

There are studies concerning childhood ocular trauma in which mean ages or age groups have been given, however in these studies age groups have not been compared to each other. Also the peak age groups are variable. While the open globe injury constituted $30 \%$ of total hospitalizations for ocular trauma in ages

Table 2. Relation of intraocular and adnexial injury by the object causing the trauma, presence of intraocular foreign body and the need for 2 or more operations following the primary repair with age

\begin{tabular}{|c|c|c|c|c|c|}
\hline & Yes & Age & No & Age & n nulu \\
\hline & $\mathrm{n}$ & Mean $\pm \mathrm{SD}$ & $\mathrm{n}$ & Mean $\pm \mathrm{SD}$ & p value \\
\hline Foreign body & 6 & $9.0 \pm 5.7$ & 73 & $7.6 \pm 4.4$ & 0.462 \\
\hline Lens injury & 38 & $7.6 \pm 4.3$ & 41 & $7.8 \pm 4.6$ & 0.843 \\
\hline Hyphema & 14 & $7.1 \pm 4.4$ & 65 & $7.8 \pm 4.5$ & 0.602 \\
\hline Retinal detachment & 8 & $7.4 \pm 5.4$ & 71 & $7.7 \pm 4.4$ & 0.824 \\
\hline Iris injury & 19 & $9.6 \pm 4.9$ & 60 & $7.1 \pm 4.1$ & 0.029 \\
\hline Two or more operations & 25 & $8.7 \pm 4.6$ & 38 & $6.4 \pm 3.8$ & 0.040 \\
\hline Adnexial injuries & 5 & $3.0 \pm 1.2$ & 74 & $8.0 \pm 4.4$ & 0.013 \\
\hline Scleral injury & 31 & $7.7 \pm 4.4$ & 48 & $7.7 \pm 4.5$ & 0.999 \\
\hline Referral in 24 hours & 53 & $7.8 \pm 4.4$ & 26 & $7.6 \pm 4.5$ & 0.855 \\
\hline
\end{tabular}

Table 3. The comparison of three age groups in terms of gender, injured eye, involvement of the sclera, causes of the injuries

\begin{tabular}{|c|c|c|c|c|c|}
\hline Gender & Injured eye & $\begin{array}{c}\text { Sclera } \\
\text { involment }\end{array}$ & $\begin{array}{l}\text { Cause of the } \\
\text { injury }\end{array}$ & $\begin{array}{c}\text { Known/unknown } \\
\text { causes }\end{array}$ & $\begin{array}{c}\text { Injury with } \\
\text { Organic/inorganic } \\
\text { objects }\end{array}$ \\
\hline
\end{tabular}

\begin{tabular}{llllll}
\hline Girl Boy Right Left & $\begin{array}{l}\text { No } \\
\text { scleral } \\
\text { injury }\end{array}$ & $\begin{array}{l}\text { Scleral Bjury tip } \\
\text { injunt Sharp Known Unknown Inorganic Organic }\end{array}$
\end{tabular}

\begin{tabular}{llllllllllllllllllllllllll} 
Age & $\mathrm{n}$ & $\%$ & $\mathrm{n}$ & $\%$ & $\mathrm{n}$ & $\%$ & $\mathrm{n}$ & $\%$ & $\mathrm{n}$ & $\%$ & $\mathrm{n}$ & $\%$ & $\mathrm{n}$ & $\%$ & $\mathrm{n}$ & $\%$ & $\mathrm{n}$ & $\%$ & $\mathrm{n}$ & $\%$ & $\mathrm{n}$ & $\%$ & $\mathrm{n}$ & $\%$ \\
$2-5$ & 10 & 30 & 23 & 70 & 15 & 46 & 18 & 54 & 22 & 67 & 11 & 33 & 16 & 53 & 14 & 47 & 30 & 91 & 3 & 9 & 29 & 97 & 1 & 3 & \\
$6-11$ & 8 & 31 & 22 & 69 & 14 & 47 & 16 & 53 & 15 & 50 & 15 & 50 & 11 & 50 & 11 & 50 & 22 & 76 & 7 & 24 & 19 & 86 & 3 & 14 \\
$12-18$ & 5 & 29 & 11 & 71 & 7 & 44 & 9 & 56 & 11 & 69 & 5 & 31 & 12 & 86 & 2 & 14 & 14 & 85 & 2 & 15 & 10 & 71 & 4 & 29 \\
$\mathrm{p}$ value & 0.930 & & & 0.982 & & & 0.306 & & & 0.072 & & & 0.245 & & & 0.056 & \\
\hline
\end{tabular}

Table 4. The comparison of three age groups in terms of seasons and place of injury

\begin{tabular}{|c|c|c|c|c|c|c|c|c|c|c|c|c|}
\hline \multirow[b]{3}{*}{ Age } & \multicolumn{8}{|c|}{ Means of the age according to seasons } & \multicolumn{4}{|c|}{ Place of the injury } \\
\hline & \multicolumn{2}{|c|}{ Winter } & \multicolumn{2}{|c|}{ Spring } & \multicolumn{2}{|c|}{ Summer } & \multicolumn{2}{|c|}{ Autumn } & \multicolumn{2}{|c|}{ Home } & \multicolumn{2}{|c|}{ Outside } \\
\hline & $\mathrm{n}$ & $\%$ & $\mathrm{n}$ & $\%$ & $\mathrm{n}$ & $\%$ & $\mathrm{n}$ & $\%$ & $\mathrm{n}$ & $\%$ & $\mathrm{n}$ & $\%$ \\
\hline $2-5$ & 9 & 27 & 3 & 9 & 8 & 24 & 13 & 40 & 21 & 64 & 12 & 36 \\
\hline $6-11$ & 9 & 30 & 6 & 20 & 11 & 37 & 4 & 13 & 20 & 67 & 10 & 33 \\
\hline $12-18$ & 4 & 25 & 4 & 25 & 6 & 38 & 2 & 12 & 4 & 25 & 12 & 75 \\
\hline $\mathrm{p}$ value & 0.1 & & & & & & & & 0.0 & & & \\
\hline
\end{tabular}


9-11, it was $15 \%$ at ages between 15 and 17 in USA (8). Bunting et al. (5) noted that $45 \%$ of all injuries have occurred under 5 year-old and this age group is a risk factor for final vision. The rates of ocular trauma change between $38 \%$ and $54 \%$ in $4-10$ age group, as given in studies from Asia $(7,11,12)$. A study from Europe reported that $54 \%$ of the total traumas were at ages between 8 and 12 (6). Armstrong et al. (2) reported that rates of eye injuries were highest in children at 1517 years of age. In our study $42 \%$ of ocular injuries took place in group 1, 38\% in group 2 and $20 \%$ in group 3. Seventy-five percent of the injuries occurred under 11 years, in accord with the studies from Asia.

The recent studies from different regions all around the world revealed the mean age for ocular injury is between $7-11$ years $(6,7,11-13)$. The mean age of openglobe injuries in pediatric group was found to be 8 $(12,13)$. The mean age is also 8 in our study, in accord with the results of other studies. Male/female ratio has been found higher in almost all studies (2). Male/female ratio is just about 2.5 fold in our study. Alpay et al. (14) reported that males had significantly higher ocular trauma rate at ages between 10 and 19. According to some publications, the rate of pediatric ocular trauma increase by age and male/female ratio increase in ocular trauma related hospitalizations $(8,15)$. We found no significant difference regarding male/female ratio between 3 age groups. In our study concerning only open-globe injuries $57 \%$ of the traumas occurred indoor, in accord with the others $(2,7,10,16)$. Armstrong et al. (2) reported that 0-4 age group has the highest risk of indoor injuries. In older age groups, the rates of outdoor trauma increase, similar to our results. In our study, $64 \%$ of open globe injuries in group 1 occurred at home. The ocular traumas most frequently occurred in spring and summer. However, the effect of age on seasonal variation has not been assessed $(2,17,18)$. Also in our study, most of the injuries took place in summer, though the majority of injuries were at autumn and winter in smaller age groups spending more time at home. The higher frequency of trauma in summer is attributed to the time spent outside away from parental supervision (2). The organic objects have been reported to be responsible for $8-22 \%$ of open-globe injuries, whereas sharp metals, scissors, knives and glass cause $45-55 \%$ of the open globe injuries $(11,19)$. In our study, $41 \%$ of the injuries were due to sharp objects and $10 \%$ due to organic materials. In $1 \%$ to $5 \%$ of pediatric age group, the causative agent could not be identified $(11,19)$. We could not identify the causative agent in $15 \%$ of the cases. We think that these children with a history of fall do not tell exactly what happened outdoor away from family supervision since they got panicked and scared. In our study, the children in adolescent group were exposed to inorganic and blunt tip objects more. This may be due to the fact that the injuries took place outdoor. The occurrence of the injuries mostly in summer and outdoor in this age group supports our idea. The smaller age groups were exposed to indoor injuries in fall and winter. The sharp objects caused injury more in smaller age groups since they are easily accessible at home. The additional adnexial injuries were noted in first group, most likely due to the relatively small area in the entire face covered by the eye, thus facilitating the injury around the eyes. By advancing age, we think that the eyes become more prone to trauma as the eyes cover a larger area in the face and with the direct impact of more severe trauma, more iris injury occurs and the need for a secondary operation increases.

\begin{tabular}{|c|c|c|c|c|c|c|c|c|c|c|c|c|c|c|c|c|c|c|c|c|c|c|c|c|}
\hline \multirow[b]{3}{*}{ Age } & \multicolumn{4}{|c|}{ Hyphema } & \multicolumn{4}{|c|}{$\begin{array}{c}2 \text { or more } \\
\text { surgery need }\end{array}$} & \multicolumn{4}{|c|}{$\begin{array}{c}\text { Retinal } \\
\text { detachment }\end{array}$} & \multicolumn{4}{|c|}{ Lens injury } & \multicolumn{4}{|c|}{ Iris injury } & \multicolumn{4}{|c|}{ Foreign body } \\
\hline & \multicolumn{2}{|c|}{ Hyphema } & \multicolumn{2}{|c|}{$\begin{array}{l}\text { No } \\
\text { hyphema }\end{array}$} & \multicolumn{2}{|c|}{ Yes } & \multicolumn{2}{|c|}{ No } & \multicolumn{2}{|c|}{$\mathrm{RD}$} & \multicolumn{2}{|l|}{$\begin{array}{l}\text { No } \\
\text { RD }\end{array}$} & \multicolumn{2}{|c|}{ Yes } & \multicolumn{2}{|l|}{ No } & \multicolumn{2}{|l|}{ Yes } & \multicolumn{2}{|l|}{ No } & \multicolumn{2}{|c|}{ Yes } & \multicolumn{2}{|l|}{ No } \\
\hline & $\mathrm{n}$ & $\%$ & $\mathrm{n}$ & $\%$ & $\mathrm{n}$ & $\%$ & $\mathrm{n}$ & $\%$ & $\mathrm{n}$ & $\%$ & $\mathrm{n}$ & $\%$ & $\mathrm{n}$ & $\%$ & $\mathrm{n}$ & $\%$ & $\mathrm{n}$ & $\%$ & $\mathrm{n}$ & $\%$ & $\mathrm{n}$ & $\%$ & $\mathrm{n}$ & $\%$ \\
\hline $2-5$ & 27 & 82 & 6 & 18 & 9 & 29 & 22 & 71 & 3 & 9 & 30 & 91 & 17 & 52 & 16 & 48 & 5 & 15 & 28 & 85 & 2 & 9 & 31 & 91 \\
\hline $6-11$ & 25 & 83 & 5 & 17 & 10 & 32 & 21 & 68 & 3 & 10 & 27 & 90 & 15 & 50 & 15 & 50 & 6 & 20 & 24 & 80 & 2 & 7 & 28 & 93 \\
\hline $12-18$ & 12 & 80 & 3 & 20 & 6 & 43 & 8 & 57 & 2 & 13 & 13 & 87 & 6 & 40 & 9 & 60 & 8 & 53 & 7 & 47 & 2 & 12 & 14 & 88 \\
\hline$p$ value & 0.96 & & & & 0.4 & & & & 0.9 & & & & 0.7 & & & & 0.01 & & & & 0.7 & 06 & & \\
\hline
\end{tabular}

RD: Retinal detachment 


\section{Conclusion}

In conclusion, the most significant difference amongst the age groups in Northwest Turkey was the place of the trauma and the properties of the objects causing the trauma. The way the trauma occurs and the severity of the trauma may affect the visual prognosis. The open globe-injury rate in Northwest Turkey is found to be higher in small age groups. The awareness of the parents and avoidance of easily accessible sharp objects may decrease the trauma rates. Both in pediatric outpatient and ophthalmology outpatient clinics the children and the families should be informed and warned. Hereby, the psychological and financial burden on the society and the family may be prevented.

\section{Ethics}

Ethics Committee Approval: This study retrospective, Informed Consent: It was taken.

Peer-review: Externally peer-reviewed.

\section{Authorship Contributions}

Surgical and Medical Practices: Berna Akova Budak, Sertaç Argun Kıvanç, Concept: Berna Akova Budak, Sertaç Argun Klvanç, Ahmet Tuncer Özmen, Design: Berna Akova Budak, Sertaç Argun Kıvanç, Ahmet Tuncer Özmen, Meral Yıldız, Data Collection or Processing: Mediha Tok Çevik, Nagihan Amuk Hamidi, Analysis or Interpretation: Berna Akova Budak, Sertaç Argun Klvanç, Ahmet Tuncer Özmen, Literature Search: Mediha Tok Çevik, Nagihan Amuk Hamidi, Ahmet Tuncer Özmen, Meral Yıldız, Writing: Berna Akova Budak, Sertaç Argun Kıvanç.

Conflict of Interest: No conflict of interest was declared by the authors.

Financial Disclosure: The authors declared that this study received no financial support.

\section{References}

1. Jandeck C, Kellner U, Bornfeld N, Foerster MH. Open globe injuries in children. Graefes Arch Clin Exp Ophthalmol 2000;238:420-6.
2. Armstrong GW,Kim JG,Linakis JG, Mello MJ, Greenberg PB.Pediatric eye injuries presenting to United States emergency departments: 20012007. Graefes Arch Clin Exp Ophthalmol 2013;251:629-36.

3. Abbott J, Shah P. The epidemiology and etiology of pediatric ocular trauma. Surv Ophthalmol 2013;58:476-85.

4. Moren Cross J, Griffin R, Owsley C, McGwin G, Jr. Pediatric eye injuries related to consumer products in the United States, 19972006. J AAPOS 2008;12:626-8.

5. Bunting H, Stephens D, Mireskandari K. Prediction of visual outcomes after open globe injury in children: a 17-year Canadian experience. J AAPOS 2013;17:43-8.

6. Malagola R, Arrico L, Migliorini R, D'Ambrosio EM, Grenga R. Ocular traumatology in children. A retrospective study. G Chir 2012;33:423-8.

7. Sharifzadeh M, Rahmanikhah E, Nakhaee N. Pattern of pediatric eye injuries in Tehran, Iran. Int Ophthalmol 2013;33:255-9.

8. Brophy M, Sinclair SA, Hostetler SG, Xiang H. Pediatric eye injury-related hospitalizations in the United States. Pediatrics 2006;117:e1263-71.

9. Williams K, Thomson D, Seto I, et al. Standard 6: age groups for pediatric trials. Pediatrics 2012;129 Suppl 3:S153-60.

10. Altıntaş L, Altıntaş O, Yüksel N, Pirhan D, Ozkan B, Cağlar Y. Pattern of open eye injuries in northwest Turkey: a retrospective study. Ulus Travma Acil Cerrahi Derg 2011;17:334-9.

11. Xu YN, Huang YS, Xie LX. Pediatric traumatic cataract and surgery outcomes in eastern China: a hospital-based study. Int J Ophthalmol 2013;6:160-4.

12. Turgut S, Perente İ, Özgün C, Ovalı T, Öngör E. Pediatric penetrating eye trauma. Ulus Travma Acil Cerrahi Derg 1997;3:58-61.

13. Ahmadabadi MN, Alipour F, Tabataei SA, Karkhane R, Rezaei $\mathrm{H}$, Ahmadabadi EN. Sharp-object-induced open-globe injuries in Iranian children admitted to a major tertiary center: a prospective review of 125 cases. Ophthalmic Res 2011;45:149-54.

14. Alpay A, Ozcan O, Uğurbaş SC, Uğurbaş SH. Eye injuries at a tertiary health centre in West Black Sea region, Turkey. Ulus Travma Acil Cerrahi Derg;18:118-24.

15. Shah MA, Shah SM, Appleware AH, Patel KD, Rehman RM, Shikhange KA. Visual outcome of traumatic cataract in pediatric age group. Eur J Ophthalmol 2012;22:956-63.

16. McGwin G, Jr., Hall TA, Seale J, Xie A, Owsley C. Consumer product-related eye injury in the United States, 1998-2002. J Safety Res 2006;37:501-6.

17. Wagner RS. Pediatric eye trauma in the summer. J Pediatr Ophthalmol Strabismus 2009;46:201.

18. Kutschke PJ. Ocular trauma in children. J Ophthalmic Nurs Technol 1994;13:117-20.

19. Uysal Y, Mutlu FM, Sobaci G. Ocular Trauma Score in childhood open-globe injuries. J Trauma 2008;65:1284-6. 